\title{
Exploring the key communicator role of exosomes in cancer microenvironment through proteomics
}

\author{
HuiSu Kim", Dong Wook Kim ${ }^{1}$ and Je-Yoel Cho ${ }^{1,2^{*}}$
}

\begin{abstract}
There have been many attempts to fully understand the mechanism of cancer behavior. Yet, how cancers develop and metastasize still remain elusive. Emerging concepts of cancer biology in recent years have focused on the communication of cancer with its microenvironment, since cancer cannot grow and live alone. Cancer needs to communicate with other cells for survival, and thus they secrete various messengers, including exosomes that contain many proteins, miRNAs, mRNAs, etc., for construction of the tumor microenvironment. Moreover, these intercellular communications between cancer and its microenvironment, including stromal cells or distant cells, can promote tumor growth, metastasis, and escape from immune surveillance. In this review, we summarized the role of proteins in the exosome as communicators between cancer and its microenvironment. Consequently, we present cancer specific exosome proteins and their unique roles in the interaction between cancer and its microenvironment. Clinically, these exosomes might provide useful biomarkers for cancer diagnosis and therapeutic tools for cancer treatment.
\end{abstract}

\section{Background}

Cell release diverse types of extracellular vesicles; apoptotic bodies whose sizes are 50 to $5,000 \mathrm{~nm}$ with their irregular lipid bilayers, as well as microvesicles whose size 50 to $1,000 \mathrm{~nm}$ is smaller than apoptotic bodies but also has an irregular shape. Exosomes are 30$100 \mathrm{~nm}$ in diameter and contain DNA, miRNA, mRNA, IncRNA, proteins, etc. within their lipid bilayer membrane [1-5] (Fig. 1). Apoptotic bodies and microvesicles are originated from cell membrane surface. Exosomes are smallest extracellular vesicles and originating from endosomes [6]. Exosomes are secreted by various cell types and conditions [7]. After being released from the donor cells the, exosomes travels through the blood and other body fluids. While traveling through the body, exosomes enter the recipient cells through membrane fusion and induce transcriptional and, even more abundantly, translational changes [8-10]. Tumor cells however secrete more exosomes than normal cells and these

\footnotetext{
* Correspondence: jeycho@snu.ac.kr

'Department of Biochemistry, BK21 Plus and Research Institute for Veterinary Science, School of Veterinary Medicine, Seoul National University, Seoul, South Korea

${ }^{2}$ Department of Biochemistry, College of Veterinary Medicine, Seoul National University, 1 Gwanak-ro, Gwanak-gu, Seoul 08826, Korea
}

cancer-derived exosomes are involved in tumorigenesis, metastasis and forming the tumor microenvironment [11]. Recently, many researches have revealed that the exosome is a mediator of cell to cell communication and can be a good candidate for a liquid biopsy biomarker [12-16]. There have been analyses of breast cancerderived exosomal proteins by liquid chromatographymass spectrometry (LC-ms/ms), which revealed that the exosome contains a variety of proteins, for example, enzymes, membrane proteins, heat shock proteins, and even transcription factors. This review discusses cancerderived exosomal proteins and their roles in the interaction with tumor microenvironment.

\section{Exosome isolation and protein digestion for proteomics}

After many research studies proved that exosomes play a role in cell to cell communication through proteins, the interest in exosomes continued growing. However, the method of exosome isolation and analysis is still debated [8]. High yield and purity can not only enhance quality but also help us to understand the exosome's role in specific conditions. Here, we will discuss exosome 


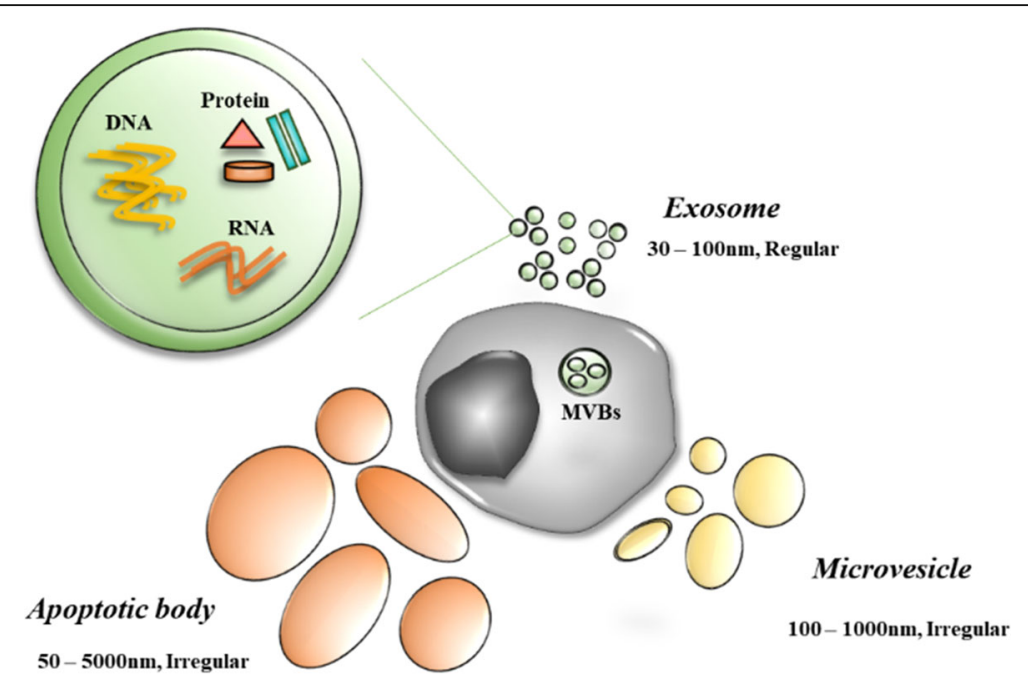

Fig. 1 Schematic description of the extracellular vesicles, Exosomes are smallest extracellular vesicles (30-100nm) secreted from endosomes. Microvesicles are small vesicles (50-1,000 nm), and apoptotic bodies are largest extracellular vesicles, both are originated from cell membrane

isolation methods and digestion methods of exosomal proteins from plasma/serum and cells.

Various exosome isolation methods have been developed $[8,17,18]$. Many of these methods can be categorized into three main categories according to the characteristics of the exosome; density, size, and immunoaffinity. First, sorting exosome by density is the most common method and utilizes differential centrifugation by varying the $g$ force. Shortly, this is started with centrifuging at $300-500 \mathrm{~g}$ to remove cells, accelerating the speed to 2,000-20,000g to remove cellular debris, and finally speeding up to $100,000-200,000 \mathrm{~g}$ for the exosome isolation. Using this method, researchers can get exosomes in the pellet. However, isolation takes a long time and requires a lot of input. The biggest drawback is relatively low efficiency and poor recovery. Recently, commercial precipitation reagents have been developed. Using a precipitate for exosome isolation has a higher yield than using an ultracentrifuge, but lower quality since the precipitate can lead to the precipitation of proteins. Second, using the smaller than $200 \mathrm{~nm}$ size characteristic of the exosome allows it to be separated by filtration and size exclusion chromatography. Filtration and size exclusion chromatography can filter out the cell membrane, sub-cellular fraction and anything that has a bigger size than the exosome. To increase efficiency and purity, many researchers use a combined method, such as filtration and ultracentrifuge, or filtration and precipitate reagents. Muller et al suggested that this combined method is better than using only one method [19]. Lastly, the immunoaffinity for isolation method uses antibodies to capture exosomal proteins. The common proteins isolated by immunoaffinity are tetraspanins such as CD9, CD63, and CD81.

After isolation of the exosome, we must lyse the lipid bilayer membrane and digest proteins to peptides for mass spectrometry (MS) analysis. Here, we summarized 3 protein digestion methods; In-gel digestion, In-sol digestion, and Filter Aided Sample Preparation (FASP) (Fig. 2) [20]. First, in In-gel digestion, lysed exosomal proteins are resolved on a polyacrylamide gel and visualized using Coomassie brilliant blue or other staining reagents. The gel is then sliced to a $1 \mathrm{~mm}$ size and destained by ammonium bicarbonate. The next steps are reduction, alkylation, and digestion. Peptides go through the process of enrichment and cleanup. Then, dried peptides are resuspended and injected into LC-ms/ms [21]. Second, for In-sol digestion, lysed exosomes are kept in an aqueous state. Exosomal proteins sequentially undergo reduction, alkylation, and digestion in the aqueous state. Like the in-gel method, peptides are then enriched and cleaned up before being injected into LC$\mathrm{ms} / \mathrm{ms}$. Lastly, in the FASP method, all of the abovementioned processes are processed on Microcon $30 \mathrm{k}$ centrifugal ultrafiltration units. Lysed exosomes are loaded onto the filter and discard the elute after centrifugation. Reduction, alkylation and digestion are all processed on the filter. Overall, each method has its advantages and disadvantages. Here, we summarized methodological properties in Table $1[21,22]$.

Cho (2015) et al., suggested that the biggest issues in exosome research arise from the exosome isolation method. Since the proper isolation method for exosome study remains debated however, we summarized exosome 

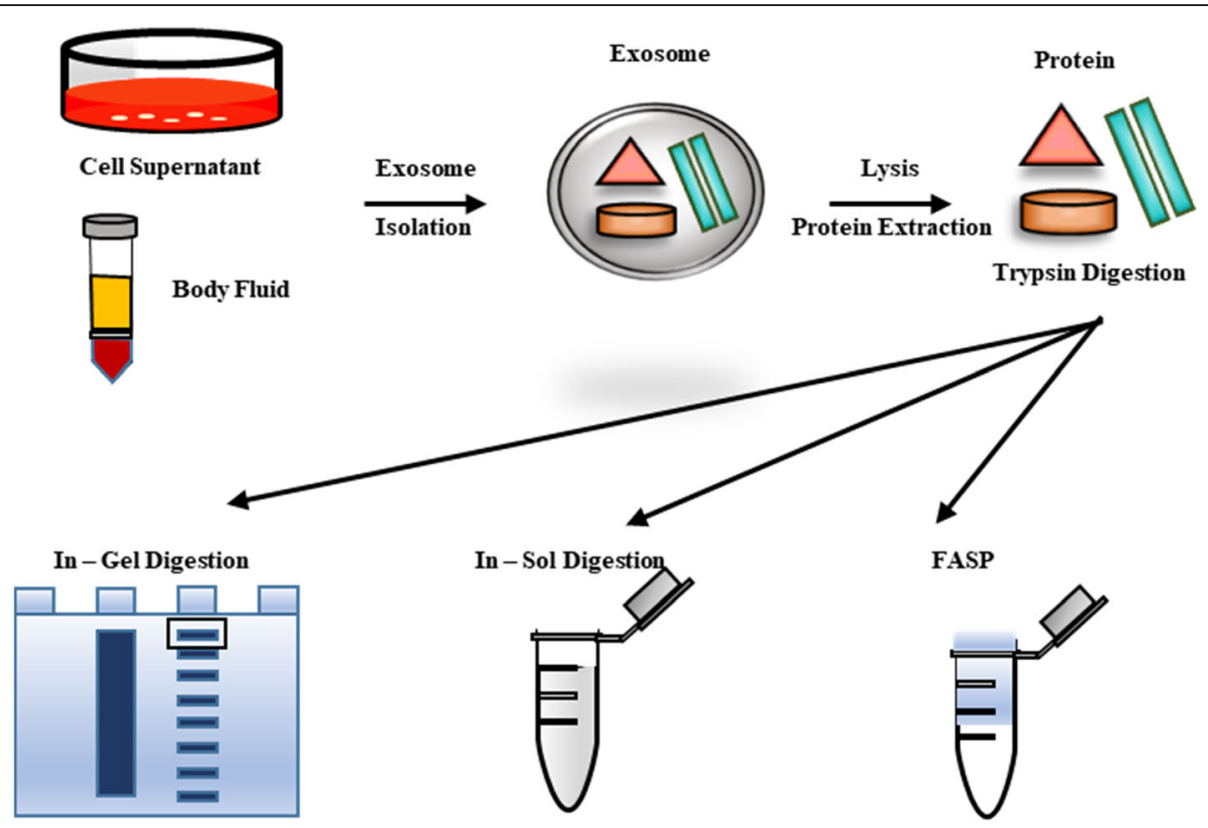

FASP
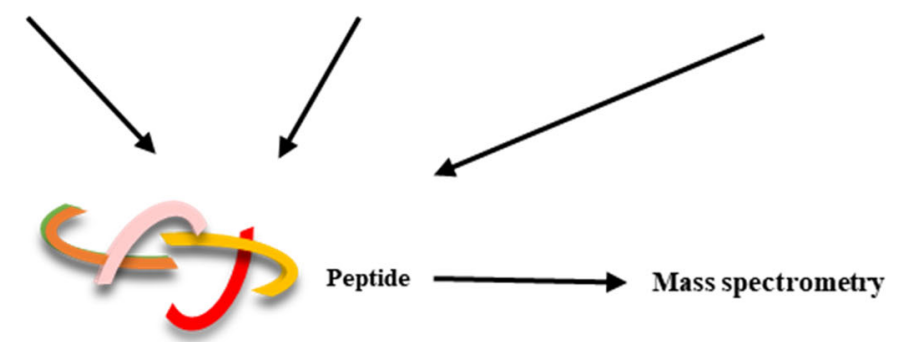

Peptide

Mass spectrometry

Fig. 2 Summarization of exosomal protein digestion methods. Exosomes from cell supernatant and body fluid are digested by (1) In-gel digestion (2) In-sol digestion and (3) FASP methods

isolation and exosomal protein digestion methods from the studies for exome proteome analyses in Table 2 .

The exosomes secreted from the cells and biological fluids are most often separated by a combined method. The most commonly used method is the fusion of ultracentrifugation and filtration. Exosomes are usually digested by the In-Gel, In- sol and FASP methods. Before the FASP method arose [61], the most used method was the In-Gel method. But the FASP method is known to have both the In-Gel and In-Sol methods' advantages, thus recently manystudies used the FASP method for digestion regardless of where exosomes came from.

\section{Cancer-derived exosomal Proteins} Breast cancer

Breast cancer is the deadliest cancer in women. One in eight women are diagnosed with breast cancer in their lifetime [62] and breast cancer accounts for 30\% of newly diagnosed cancers in women [63]. For the last 10 years breast cancers' death rates and incidence rates in The United States have risen each year. The exosome has been revealed as a potential liquid biopsy biomarker and numerous studies using liquid chromatographymass spectrometry (LC-ms/ms) have revealed that cancer derived exosomes contains various proteins,

Table 1 Advantages and Disadvantages of proteomic digestion techniques

\begin{tabular}{lll}
\hline Digestion Method & Advantages & Disadvantages \\
\hline In-gel Digestion & $\begin{array}{l}\text { Reproducible, Cost effective, Removal of mass spectrometry } \\
\text { incompatible detergents (SDS, Triton etc.) and contaminants, } \\
\text { Wide cover range }\end{array}$ & $\begin{array}{l}\text { Time consuming, Inacceptable for extremely acidic or basic } \\
\text { and high or low molecular weight proteins and membrane } \\
\text { proteins }\end{array}$ \\
In-sol Digestion & Require less time & Inacceptable for low resolubilization proteins \\
FASP & Acceptable for membrane proteins, Removal of mass & Loss of proteins, Bad repoducibility, Require large amount of \\
& spectrometry incompatible detergents (SDS, Triton etc.) & protein sample (>50ug) \\
\hline
\end{tabular}


Table 2. Summarization of used techniques for cancer-derived exosomes isolation and exosomal protein digestion methods

\begin{tabular}{llll}
\hline $\begin{array}{l}\text { Origin of } \\
\text { Exosome }\end{array}$ & Isolation Method & $\begin{array}{l}\text { Digestion } \\
\text { Method }\end{array}$ & Reference \\
\hline Cell & Ultracentrifuge & In-Gel Digestion & {$[23-30]$} \\
& & In-Sol Digestion & {$[26,31,32]$} \\
& $\begin{array}{l}\text { Precipitation } \\
\text { reagent }\end{array}$ & In-Gel Digestion & {$[33-37]$} \\
& Combined method & In-Gel Digestion & {$[28,35,36,40-51$} \\
& & & ] \\
& & In-Sol Digestion & {$[52-54]$} \\
Plasma/ & Ultracentrifuge & FASP & {$[51,55-59]$} \\
& & In-Sol Digestion & {$[60]$} \\
& \multirow{2}{*}{ Combined method } & In-Gel Digestion & {$[43]$} \\
& & In-Sol Digestion & {$[44,52]$} \\
& & FASP & {$[51,57,58]$} \\
\hline
\end{tabular}

including enzymes, membrane proteins, heat shock proteins, and even transcription factors.

There are many studies on different types of breast cancer exosomes; the cell line derived exosomes described, or exosomes derived from breast cancer patient biological fluids. An early exosome proteome study identified that exosomes derived from breast cancer cell lines MCF-7 and MDA-MB-231 have 59 and 88 proteins, respectively [64]. The MDA-MB-231 derived exosome contained more enzymatic proteins than the MCF7 derived exosome. The number of common proteins between the two cell lines are 27. These include cytoskeleton proteins such as $\beta$-actin, tubulin- $\beta$, and integrins; membrane proteins like BASP1; enzymes including enolase $\alpha$ and PRDX1; ribosomal proteins like RS27A; heat shock proteins including HSP90A, HSP90B, HSP7C; and epigenetic modification related proteins such as Histone proteins and 14-3-3 proteins. $\beta$-actin and tubulin- $\beta$ are associated with breast cancer metastasis $[65,66]$. Overexpression of these proteins in breast cancers show high metastatic potential. It has already been demonstrated by Hoshino et al that exosomal integrins $\alpha 6 / \beta 4$ and $\alpha 6 / \beta 1$ were related to lung metastasis and integrin $\alpha \mathrm{v} / \beta 5$ was related to liver metastasis [32]. They also found that exosomal integrins activate the Src signaling pathway in the recipient cells, which induces the inflammatory response. There is no study yet regarding the correlation of BASP1 and breast cancer. But there is a study demonstrating that BASP1 overexpression promotes cervical cancer cell progression and can be a prognostic marker [67]. Enolase $\alpha$ is the glycolytic enzyme that catalyzes fructose-1,6-biphosphate to glyceraldehyde 3-phosphate and dihydroxyacetone phosphate. Research has revealed that an increased level of enolase $\alpha$ is related to breast cancer metastasis and drug resistance $[68,69]$. PRDX1 is an antioxidant enzyme, but its role in breast cancer is controversial. It is, however, clearly overexpressed in breast cancer tissue relative to normal tissue [70]. Recently, Bajor et al demonstrated that PRDX1 is involved in reducing exogenous oxidative stress and induces cell growth in breast cancer [71]. The H2B1 (Histone H2B type 1-C/3/F/G/I) proteins are related to epigenetic regulation. Exosomal histone proteins have been detected in cancers and other diseases, and even in normal conditions [72, 73]. However, there are quantitative differences between those detected in cancer versus normal conditions. The role of exosomal histone proteins in recipient cells is currently controversial, but exosomes also contain 14-3-3 protein, which has been shown to bind with histone proteins [74, 75]. So, H2B1 can potentially induce epigenetic changes in recipient cells by binding with exosomal 14-3-3 proteins.

The most abundant MCF-7 derived exosomal proteins are the structural proteins such as fibronectin, annexin A1, vimentin, actin $\alpha$, etc., and heat shock proteins. Fibronectin is also known to induce tumor progression and metastasis. The amount of fibronectin is much higher in the exosome of breast cancer patients' plasma than normal plasma exosome [76]. A study revealed that fibronectin secreted by myeloma cell is attached to the recipient cell membrane and turns on p38 and pERK signaling [77]. Activated p38 and pERK signaling induces myeloma cell progression by activating DKK1 and MMP-9. The second largest presence after fibronectin is annexin $\mathrm{A} 1$, which is attached to the phospholipid membrane. Annexin A1 inhibits phospholipase A2 and induces anti-inflammatory activity [78]. Similarly, it is suggested that annexin A1 induces metastasis, macrophage polarization, and poor prognosis [79]. This provides support for Okano et al's claim that increase in the amount of annexin A1 results in cell invasion which progresses into metastasis [80]. 5'-NTD (5'- nucleosidase, CD73) is the next dominant protein in the exosome of MCF7 cells. 5'-NTD is the enzyme that catalyzes the carbon 5'-nucleoside phosphorolytic cleavage and thus is essential for recycling adenosine and cell growth [81]. It is also overexpressed in many breast cancers. When 5'NTD is overexpressed in breast cancer cells, it accelerated adhesion, migration and invasion of cancer cells [81-84]. So, it can be a clue for how MCF7 changes it microenvironment. That is cancer cells secretes a metastasis accelerator via the exosome. The 5'-NTD is also related to the immune response [85]. Exosomal 5'-NTD produces adenosine and indirectly modulates regulatory $\mathrm{T}$ cell $\left(\mathrm{T}_{\text {reg }}\right)$ mediated immunity. Immune modulation for $\mathrm{T}_{\text {reg }}$ by 5 '-NTD in cancer microenvironment also helps cancer cells for their growth and metastasis. Among the 59 proteins identified in the exosome 
secreted by MCF7, 30 proteins have been known to participate in breast cancer growth, metastasis, and chemoresistance.

The most abundant MDA-MD-231 derived exosomal protein is $\beta$-actin, which is frequently used as a housekeeping gene in the exosome. There are also other structural proteins in the exosome such as tubulin- $\beta$ and keratins. In general, these cytoskeletal proteins of $\beta$-actin, tubulin- $\beta$ and keratin are all associated with breast cancer metastasis. Fourteen other exosomal proteins are also known to be involved in the metastasis of breast cancer $[65,66,86]$. Tubulin- $\beta$ is also known to induce chemotherapy resistance [87]. Palazzolo et al identified 32 proteins that are more abundant in the MDA-MB-231 exosome than MCF7 cells [88]. Of these 32 proteins, 5 overlap with exosomal proteins that Kruger et al identified. These 5 proteins, 14-3-3 protein epsilon, $\beta$-actin, annexin A1/5, heat shock protein 71 and galectin 3 binding protein can be potential biomarker candidates for breast cancer-derived exosome. In addition, a study also suggested del-1 as an early stage breast cancer exosome biomarker [89].

Klinke et al identified 27 and 28 proteins from other breast cancer cell lines, BT-474 and SKBR-3, respectively by secretome profiling through LC-ms/ms [90]. Some common proteins with MCF7 and MDA-MB-231 -derived exosomal proteins emerged, for example, $\beta$-actin, heat shock proteins, aldolase $\alpha$, enolase $\alpha, 14-3-3$ proteins, etc. BT-474 and SKBR-3 are HER2 positive cell lines, and secreted exosomes highly enriched with proteins involved in antigen presenting (HSPA5, CALR, PSME1,2, PSMA 3,6, PSMB 2,4, and HLA-C) and glycolytic metabolism (G6PD, TP1, and PGAM1). These proteins could lead to cancer immune-surveillance and malfunctioned energy synthesis in breast cancer microenvironment [91-93]. In addition, BT-474-derived exosomal proteins have a strong relation with neutrophil GO terms; DDX3X, VCP, HSP90AA1, ILF2, HSPA8, PNP, MME, MME2, PAB37, SERPINB6, GDI2, ALDOA, PGAM1, and GPI, which are related with neutrophil degranulation, mediated immunity and neutrophil activation. Immune suppression by cancer exosomes and its relation to neutrophils have already been studied [94]. In a breast cancer-bearing mice model, neutrophils were activated and exosome levels in blood were much higher than the normal control group. It is also suggested that exosomes derived from tumors interact with neutrophils and induce cancer-associated thrombosis. All these evidences strongly suggest the importance of cancerderived exosome in the immune modulation.

In addition, exosomes are thought to help increase breast cancer tumorigenesis. This is due to the specificity of the proteins found in the exosomes. Firstly, the exosomes isolated from the serum of breast cancer patients had high amounts of survivin [95], a protein that controls anti-apoptosis of the surrounding cells, and exosomes isolated from the cell line had large amounts of MTA1 [96], a protein that promotes proliferation, . Secondly, there is a large amount of drug and chemoresistance proteins in the exosome. GSTP1, TGF- $\beta 1$, TPRC5, and UCH-L1 are examples [97-100]. Finally, proteins that induce metastasis present highly in exosomes. A typical example is nephronectin, which has been reported to be high in the serum of patients with metastases [101]. It is also notable that analysis of breast cancer cells and their metastasized cancer cell derived exosomes revealed that integrin $\alpha 6 / \beta 4$, caveolin- 1 , periostin and myoferlin are more enriched in metastasized cancer cells than primary breast cancer cells [31, 32, 36, 102], although their roles need to be further investigated. These proteins might serve as biomarker candidates for breast cancer.

\section{Lung Cancer}

Lung cancer is the most common cause of cancer related death in both sexes and also shows the highest incidence rate among cancer in the United States [63]. Non-small cell lung cancer (NSCLC) accounts for the largest proportion of lung cancer patients. This is further categorized into adenocarcinoma, squamous cell carcinoma, and large cell carcinoma. Lung cancer is found later than any other cancer because it has no symptoms that can be discerned through self-awareness. Thus, regardless of the many developed treatments for lung cancer, after diagnosis it is often too late to treat. This leads to a poor 5-year survival rate and motivates the search for scanning biomarkers. Here, we classify and summarize the roles of the NSCLC-derived exosomal proteins.

Clark et al analyzed two of the NSCLC cell lines, A549 and HCC827 [51]. They normalized the LC-ms/ms data with normal lung cell line HBE3. The number of proteins that expressed twice more in A549 than normal HBE3 is 58. Mucin $5 \mathrm{AC}$ and B proteins are highly enriched in A549 derived exosome. Mucin 5 AC and B are known to only be expressed in lung adenocarcinoma. Overexpression of these proteins leads to lung cancer relapse and metastasis [103, 104]. Furthermore, there are Annexin proteins, ADAM10, EGFR, integrin, JAK, and metabolism related enzymes found in the A549 derived exosome. Of the 58 proteins, $12(20 \%)$ are correlated with neutrophil degranulation and neutrophil-mediated immunity (JUP, C3, VCP, CD44, etc.). The HCC827 exosome has 93 more proteins than the HBE3 derived exosome. The most abundant protein is desmoglein-2. It has been reported that desmoglein-2 is overexpressed in NSCLC tissues and induce NSCLC growth by regulating 
p27 and CDK2 [105]. The next most enriched protein is EGFR. Given that EGFR is an oncogene in lung cancer, this can be a powerful clue to explain the exosome's extreme tumorigenicity role in the neighboring microenvironment [106]. HCC827 derived exosomes also contain several kinds of other proteins; Integrin, Annexin proteins, guanine nucleotide-binding proteins (GPCR), and 14-3-3 proteins. Like in the A549 derived exosomal proteins, there are also neutrophil-related proteins enriched in the $\mathrm{HCC} 287$ derived exosome as well (22.5\%).

The exosomes secreted by lung cancer, like the exosomes secreted by breast cancer, are also involved in tumorigenesis. Most cancers are characterized by metastasis only to certain organs, called organotropic metastasis [107]. Recent studies suggest that exosomes are also involved in organotropic metastasis [32]. Integrin plays a very important role. Hoshino et al revealed that treatment of exosomes isolated from lung cancer cells redirects lung cancer cells to metastasize to bone [32]. Exosomal integrins $\alpha 6 \beta 4$ and $\alpha 6 \beta 1$ are involved in lung cancer organotropic metastasis. As such, proteins in exosomes can induce metastasis by reprogramming cells. Exosomal Leucine-Rich-Alpha2-Glycoprotein 1 (LRG1) secreted from lung cancer cells induces angiogenesis through TGF-beta signaling in recipient cells [108]. This exosomal protein is also found in exosomes isolated from urine in patients with lung cancer [109], which may serve as a good prognostic marker. Another example is T-cell immunoglobulin- mucin-domaincontaining molecule 3 (Tim-3) and its ligand Galectin-9 (Gal-9). Tim3 and Gal-9 exhibit anti-tumor immune responses, by blocking Th1 type immune responses [110]. Both proteins were found to be higher in the plasma derived exosomes of lung squamous cell carcinoma patients than in lung adenocarcinoma patients [110]. It is not yet known why these two proteins are contained in the exosome. Yet Tim-3 and Gal-9, can be used as prognostic and diagnostic markers of lung cancers.

NY-SEO-1, EGFR, PLAP, and EpCam were high in exosomes isolated from the plasma of lung cancer patients [111], and Vykoukal et al also revealed that SGRN, TPM3, THBS1, and HUWE1 levels in plasma-derived exosomes in lung cancer patients is higher than control group [112]. EGFR is a protein that is highly related to lung cancer, and is abundant in exosomes isolated from lung cancer cells, lung biopsies and plasma, thus making it the most powerful biomarker from the revealed candidates $[111,113,114]$. Exosomes derived from NCIH838, another NSCLC cell line, contain more MUC1 as revealed in patients' plasma exosomes. Other report also revealed that MUC1 in NSCLC patient plasma exosome as much higher than that in the normal control group plasma exosome [115].

\section{Other cancers}

Among all women and men diagnosed with cancer each year, there is a high proportion of people diagnosed with colon cancer [63]. Colon cancer cell derived exosomal proteins are identified by Choi et al [42] and Mathivanan et el [33]. The common proteins of both studies are related with cancer progression and metastasis. Choi et al also suggested that the identified proteins have relation with immune modulation. Furthermore, human colon cancer ascites derived exosomes have similar tumorigenesis potential with proteins related to cancer progression, immune modulation, and metastasis [116]. Not only ascites, but also serum exosome can be a good diagnostic marker. Annexin proteins, and tspan 1 from the serum exosome are suggested colon cancer diagnostic markers [35, 117]. However, most cancer derived exosomes, as mentioned in breast and lung cancer derived exosomes as above, contain a lot more annexin and tetraspanin proteins than normal control derived exosome. So, these two proteins rather are pan-cancer exosome proteins.

Pancreatic cancer incidence and death rate have been increasing. Moreover, the 5-year relative survival rates of pancreatic cancer is only $9 \%$, whereas other cancers such as prostate is $98 \%$ and melanoma is $92 \%$ [63]. Pancreatic cancer cell derived exosome that induce metastasis [118, 119] and chemoresistance [27] have been revealed. Several proteins, glypican-1, CD44, Tspan8, EpCam, MET and $\mathrm{CD} 104$, have been suggested as pancreatic cancer exosome-derived biomarkers [31, 120].

Renal cancer incidence rate is 3 to $5 \%$ for both males and females, but there is no accurate biomarker for renal cancer. Raimondo et al identified renal cancer patients' urinary exosomes [121]. They suggested 10 proteins for renal cancer exsome biomarker, 5 of which are abundant in renal cancer patients; matrix metalloproteinase 9 (MMP-9), ceruloplasmin (CP), podocalyxin (PODXL), dickkopf related protein 4 (DKK4) and carbonic anhydrase IX (CAIX). Oppositely, aquaporin-1 (AQP1), extracellular Matrix metalloproteinase Inducer (EMMPRIN), neprilysin (CD10), dipeptidase 1 and syntenin-1 are abundant in the exosome of healthy control. They claimed that these 10 proteins have great potential for early stage diagnosis of renal cancer with clinical value. A summary of selected exosomal proteins is given in Table 3.

\section{The role of exosome proteins in tumor microenvironment: Friend or Foe ?} Tumor microenvironment

Many approaches to conquer cancer are ongoing all over the world. Nevertheless, incidence and death rates of cancer are on the rise every year [63]. The main cause of the increasing incidence rate and mortality is not only primary tumors, but also distant tumors [122]. Many 
Table 3 Description of the selected exosomal proteins in cancer

\begin{tabular}{|c|c|c|c|}
\hline & \\
\hline & Description & Exosomal Protein & Description \\
\hline \multicolumn{2}{|l|}{ Breast Cancer } & \multirow{2}{*}{$\begin{array}{l}\text { PLAP } \\
\text { EpCam }\end{array}$} & Overexpressed in lung cancer [111] \\
\hline$\beta$-actin & Breast cancer metastasis [65] & & Overexpressed in lung cancer [111] \\
\hline \multirow[t]{2}{*}{ Tubulin- $\beta$} & \multirow{2}{*}{$\begin{array}{l}\text { Breast cancer metastasis, } \\
\text { chemotheray resistance }[66,87]\end{array}$} & \multirow{2}{*}{$\begin{array}{l}\text { SGRN } \\
\text { TPM3 }\end{array}$} & Overexpressed in lung cancer [112] \\
\hline & & & Overexpressed in lung cancer [112] \\
\hline Integrin a6/ß4, a6/ß1 & Lung metastasis [32] & THBS1 & Overexpressed in lung cancer [112] \\
\hline Integrinav/ $\beta 5$ & Liver metastasis [32] & HUWE1 & Overexpressed in lung cancer [112] \\
\hline BASP1 & $\begin{array}{l}\text { Overexpression leads to ovarian } \\
\text { cancer cell progression [67] }\end{array}$ & MUC 1 & \multirow[t]{2}{*}{ Overexpressed in lung cancer [112] } \\
\hline \multirow[t]{2}{*}{ Enolase A } & \multirow{2}{*}{$\begin{array}{l}\text { Breast cancer metastasis and drug } \\
\text { resistance }[68,69]\end{array}$} & Colon Cancer & \\
\hline & & Annexin family & $\begin{array}{l}\text { Colon cancer progression and } \\
\text { metastasis }[33,42]\end{array}$ \\
\hline PRDX1 & $\begin{array}{l}\text { Induce cell growth in breast cancer } \\
\text { and overexpressed in breast } \\
\text { cancer [70] }\end{array}$ & Tetraspanin 1 & $\begin{array}{l}\text { Colon cancer progression and } \\
\text { metastasis }[33,42]\end{array}$ \\
\hline \multirow[t]{2}{*}{ 14-3-3 protein } & \multirow{2}{*}{$\begin{array}{l}\text { Bind to histone protiens and induce } \\
\text { epigenetic changes [75] }\end{array}$} & Pancreatic Cancer & \\
\hline & & Glypican-1 & Abundant in pancreatic cancer \\
\hline \multirow[t]{2}{*}{ Fibronectin } & \multirow{2}{*}{$\begin{array}{l}\text { Tumor progression and } \\
\text { metastasis [76] }\end{array}$} & & exosome $[31,120]$ \\
\hline & & CD44 & Abundant in pancreatic cancer \\
\hline \multirow[t]{2}{*}{ Annexin A1 } & \multirow{2}{*}{$\begin{array}{l}\text { Induce tumor metastasis and } \\
\text { macrophage polarization [78-80] }\end{array}$} & & exosome $[31,120]$ \\
\hline & & Tspan 8 & Abundant in pancreatic cancer \\
\hline \multirow[t]{2}{*}{$5^{\prime}-\mathrm{NTD}$} & \multirow{2}{*}{$\begin{array}{l}\text { Overexpressed in breast cancer cells } \\
\text { and induce metastasis [81-85] }\end{array}$} & & exosome $[31,120]$ \\
\hline & & EpCam & $\begin{array}{l}\text { Abundant in pancreatic cancer } \\
\text { exosome }[31,120]\end{array}$ \\
\hline Survivin & $\begin{array}{l}\text { Overexpressed in breast cancer } \\
\text { serum derived exoxome, Anti } \\
\text { apoptosis [95] }\end{array}$ & MET & $\begin{array}{l}\text { Abundant in pancreatic cancer } \\
\text { exosome }[31,120]\end{array}$ \\
\hline MTA1 & Promote proliferation [96] & CD104 & Abundant in pancreatic cancer \\
\hline GSTP1 & $\begin{array}{l}\text { Drug and chemotherapy } \\
\text { resistance [97] }\end{array}$ & Renal Cancer & exosome $[31,120]$ \\
\hline TGF- $\beta 1$ & Drug resistance [98] & MMP-9 & Abundant in renal cancer \\
\hline TPRC5 & Chemotherapy resistance [99] & & exosome [121] \\
\hline UCH-L1 & Chemotherapy resistance [100] & $\mathrm{CP}$ & Abundant in renal cancer \\
\hline Nephronectin & Induce tumor mestasis [101] & & \\
\hline Caveolin-1 & $\begin{array}{l}\text { Enriched in metastasized cancer } \\
\text { cell [36] }\end{array}$ & PODXL & $\begin{array}{l}\text { Abundant in renal cancer } \\
\text { exosome [121] }\end{array}$ \\
\hline Periostin & $\begin{array}{l}\text { Enriched in metastasized cancer } \\
\text { cell [102] }\end{array}$ & DKK4 & $\begin{array}{l}\text { Abundant in renal cancer } \\
\text { exosome [121] }\end{array}$ \\
\hline Myoferlin & $\begin{array}{l}\text { Enriched in metastasized cancer } \\
\text { cell [31] }\end{array}$ & CAIX & $\begin{array}{l}\text { Abundant in renal cancer } \\
\text { exosome [121] }\end{array}$ \\
\hline Lung Cancer & & AQP1 & $\begin{array}{l}\text { Abundant in renal cancer } \\
\text { exosome [121] }\end{array}$ \\
\hline Mucin $5 \mathrm{AC}, \mathrm{B}$ & $\begin{array}{l}\text { Lung cancer relapse and } \\
\text { metastasis }[103,104]\end{array}$ & EMMPRIN & $\begin{array}{l}\text { Abundant in renal cancer } \\
\text { exosome [121] }\end{array}$ \\
\hline Desmoglein-2 & $\begin{array}{l}\text { overspressed in non small cell } \\
\text { lung cancer and induce cell } \\
\text { growth [105] }\end{array}$ & CD10 & $\begin{array}{l}\text { Abundant in renal cancer } \\
\text { exosome [121] }\end{array}$ \\
\hline EGFR & $\begin{array}{l}\text { Oncogene in lung cancer } \\
{[106,111,113,114]}\end{array}$ & Dipeptidase 1 & $\begin{array}{l}\text { Abundant in renal cancer } \\
\text { exosome [121] }\end{array}$ \\
\hline LRG1 & Induce angiogenesis [108] & Syntenin-1 & $\begin{array}{l}\text { Abundant in renal cancer } \\
\text { exosome [121] }\end{array}$ \\
\hline Tim-3 & Induce anti-tumor immune & & \\
\hline
\end{tabular}

Table 3 Description of the selected exosomal proteins in cancer (Continued) 
researchers have been trying to understand the mechanism of metastasis to find a cure the cancer [123-125]. A rising concept for the metastasis mechanism is that the tumor is collaborating with the tumor microenvironment through exosomes.

The tumor microenvironment consists of immune cells, fibroblasts, the extracellular matrix, basement membrane, endothelial cells, and cancer cells [126-129]. Several roles of the tumor microenvironment have been suggested [126]. Component cells of the tumor microenvironment have roles in tumor initiation, progression, and metastasis. Many studies have revealed that the components of the tumor microenvironment communicate via exosomes $[1,130-134]$. Here, we summarized potential roles of the exosome between cancer cells and tumor microenvironment cells, and the effect on tumorigenesis (Fig. 3).

\section{Cancer associated fibroblast (CAF)}

A predominant stromal cell component of the tumor microenvironment is activated by a fibroblast, termed cancer-associated fibroblast (CAF) [135]. Several studies have revealed that CAFs are highly involved in tumor progression [136-138]. Mammary carcinoma-derived exosomes induce mammary fibroblast motility by transferring AHNAK [139]. As such, the exosome secreted by cancer cells can affect fibroblasts, but here we also discuss how fibroblast-derived exosome can affect cancer cells. Many researchers have suggested that CAFs have a relation to cancer proliferation, chemoresistance, and metastasis. Takasugi et al demonstrated that senescent fibroblast-derived exosome can induce MCF7 cell proliferation by transferring EphA2 [140]. In pancreatic cancer, it is reported that chemotherapy stimulated CAFs to release more exosomes, which in turn promoted recipient cancer epithelial cells' proliferation and drug resistance [141]. Exosomes secreted by CAFs also induce epithelial-mesenchymal transition (EMT), migration, and invasion, resulting in metastasis and cell growth of bladder cancer by activating IL-6 signaling [142]. TGF $\beta 1$ is enriched in ovarian CAFs and affects ovarian cancer cells into EMT by SMAD signaling activation [143]. In lung cancer, CAF-derived exosome also enhance metastasis by activation of the IL-6/STAT3 signaling pathway [144]. Furthermore, exosomes secreted by CAFs can affect chemotherapy resistance [145]. It is suggested CAFs-derived exosome in colorectal cancer stem cells can promote drug resistance and enhance cancer stem cell properties and also growth.

\section{Natural killer (NK) cell}

Natural killer (NK) cells are large granular cytotoxic lymphocytes that kill the target cancer cells without stimuli. There are several mechanisms by which NK cell-derived exosomes kill the recipient cells [146]. Activated NK cell-derived exosomes are cytotoxic because they can induce the cell death pathway by perforin (PFN), granzymes (Gzm-A/B) and granulysin (GNLY). Wen et al suggested that activated NK cell exosomes deliver caspase inducers which lead to cancer death by activation of the caspase-dependent cell death pathway. Perforin is delivered to form the pores and granzymes

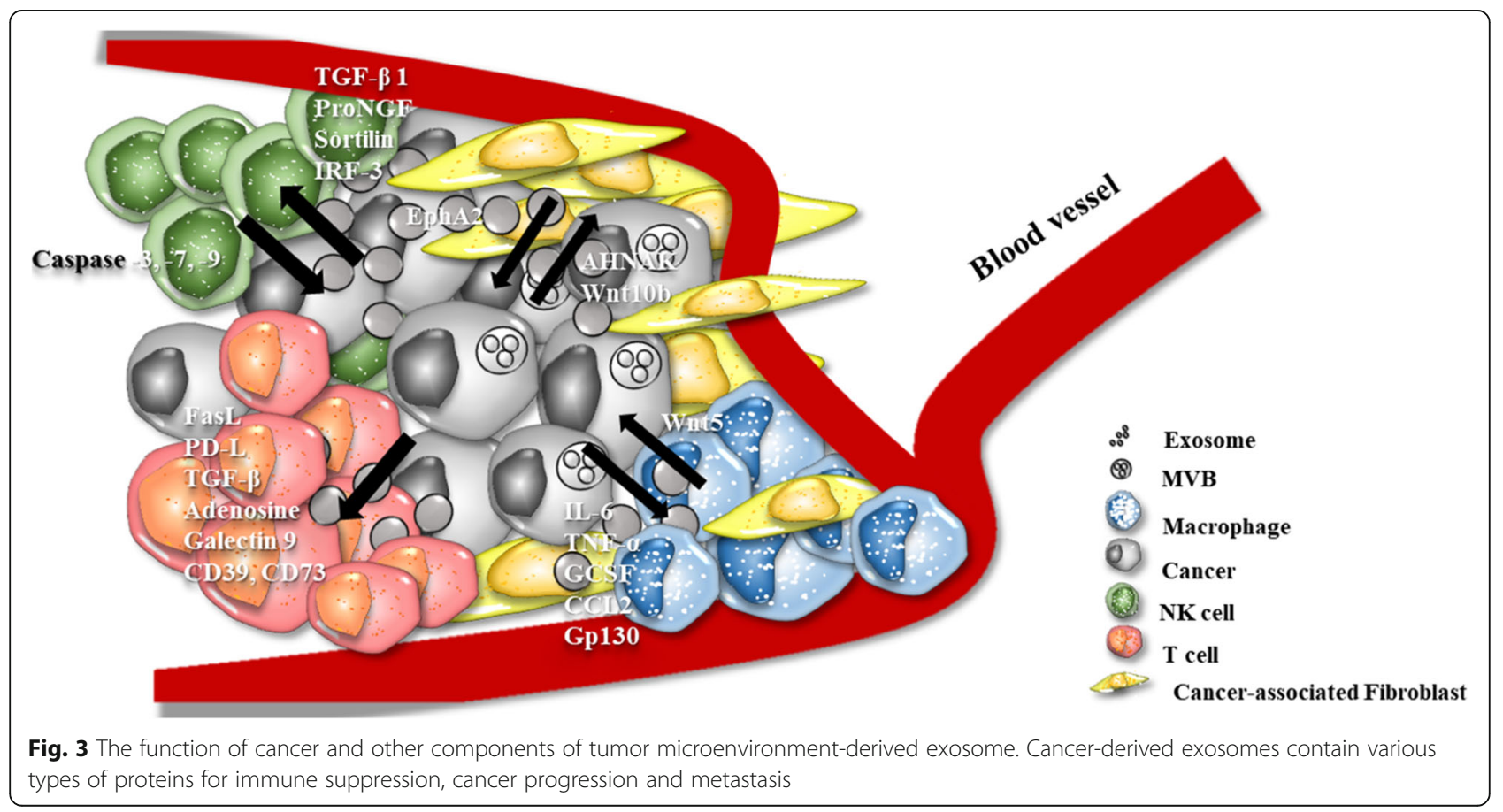


enter into the recipient cells. Granzymes induce caspasedependent and -independent cell death. Cancer cells incubated with activated NK cells showed an increased expression of activated caspase-3, -7, and -9 [147]. Prostate cancer-derived exosomes downregulate NKG2D expression on NK cells and CD8+ T-cells. This leads to downregulation of NKG2D-mediated cytotoxic response in prostate cancer patients via immune escape [148]. Berchem et al showed that hypoxic tumor-derived exosomes transfer TGF- $\beta 1$ to NK cells, which leads to the down regulation of NK cell's surface expression of NKG2D receptor [149]. Decreasing NKG2D inhibits NK cell function. Renal cancer cell-derived exosomes are enriched with TGF- $\beta 1$ and activate the TGF- $\beta 1 /$ SMAD pathway in NK cells to facilitate immune escape [150]. Another mechanism of NK cell immune response escape is related to p75NTR. NK cells in tumor microenvironment have high expression of p75NTR and exosomes secreted by lung cancer contain proNGF and sortilin, which bind to p75NTR and induce NK cell apoptosis [151]. Interestingly, exosomes released from cancer cells do not always inhibit the activity of NK cells. Wang et al revealed that ovarian cancer cell-derived exosomes enhance the cytotoxicity effect of NK cells [152]. Exosomes secreted by ovarian cancer cell contain phosphorylated IRF-3 that promotes NK cell cytotoxicity by inducing interferon gene expression in NK cells.

\section{T-cell}

Cancer-derived exosomes are known as immune suppressors because they can inactivate effector $\mathrm{T}$ cells and induce $\mathrm{T}$ cell apoptosis. There were a lot of research conducted on cancer-derived exosomes and $\mathrm{T}$ cell interaction. Cancer-derived exosomes could induce $\mathrm{T}$ cell suppression by delivering Fas ligand (FasL), PD-L1, TGF- $\beta$, adenosine and galectin-9. Abusamra et al demonstrated that prostate cancer cell-derived exosomes have FasL that induces $\mathrm{T}$ cell apoptosis upon delivery by caspase activation [153]. Colorectal cancer-derived exosomes have shown the same effect on $\mathrm{T}$ cell apoptosis [154]. The exosome isolated from head and neck cancer patients' serum also induces $\mathrm{T}$ cell apoptosis [155]. Tumor cells expressing PD-L1 in their membrane can escape form the immune response. PD-L1 is also detected in cancer-derived exosomes. Prostate and melanoma cancer cell-derived exosomal PD-L1 binds to effector $\mathrm{T}$ cell's membrane $\mathrm{PD}-1$ receptor, thereby impairing their growth [156]. Melanoma patients' circulating exosomes also have PD-L1, which also induces immune surveillance.

Exosomal TGF- $\beta 1$ is a well-known immune surveillance factor [157]. Hypoxia conditioned BT-474 and MDA-MB-231 secreted more exosomes than normoxia condition. These exosomes have an increase in TGF- $\beta$ which inhibits $\mathrm{T}$ cell proliferation. Colorectal cancerderived exosomes were enriched with TGF- $\beta 1$, which induces alteration of $\mathrm{T}$ cell phenotype to $\mathrm{T}$ regulatory cells by activating TGF- $\beta /$ Smad signaling and inactivating SAPK signaling [158]. Prostate cancer cell line-derived exosomes also contribute to immune evasion by transferring exosomal TGP- $\beta 1$ [159].

Adenosine is also a key factor in a known pathway that induces $\mathrm{T}$ cell suppression. Tumor exosomes have been known to contain CD39 and CD73 on the membrane surface. Exosome-mediated transfer of CD39 and CD73 leads to hydrolysis of ATP to adenosine. Accumulated adenosines participate in $\mathrm{T}$ cell inactivation by binding with their receptors (A1, A2A, A2B, and A3) [160]. Adenosine binds their receptors in $T_{\text {reg }}$ cells and triggers the cyclic AMP (cAMP) and protein kinase A (PKA) signal [161]. This signal can regulate either survival or apoptosis of the $\mathrm{T}$ cell, depending on the signal strength and duration [162].

Galectin also has a role in tumor-derived exosome induced immune escape. Galectin-1 is a type of $\beta$ galactosidase protein expressed in immune cells. Recently, it has been shown that tumors secreting galectin-1 on a high level affect immune cells by binding to $\mathrm{N}$ acetyllactosamine on the $\mathrm{T}$ cell membrane. Interaction of galectin-1 and the galectin ligand induces immune escape through $\mathrm{T}$ cell apoptosis [163]. It is also demonstrated enrichment of galectin in head and neck cancer-derived exosome induced suppression of $\mathrm{CD}^{+} \mathrm{T}$ cell [164].

\section{Macrophage}

Macrophages belong to the innate immune system. Macrophages are divided into two types by Th1 and Th2 polarization, which are called M1 and M2, and have the characteristics of pro-inflammatory and anti-inflammatory, respectively [165]. Tumor-associated macrophages (TAMs) consist of M2 characteristic macrophages and promote angiogenesis, invasion, and metastasis [166]. M2 macrophages secrete tumor metastasis supporting cytokines such as CCL2, MIP2, IL-8, and IL-R $\alpha$ and attenuating antitumor cytokines such as TIMP-1, IFN- $\gamma$, IL-1R $\alpha$, IL-13, and IL-16 $[167,168]$. Chen et al described how colorectal cancerderived exosomes induce M2 macrophages by cytoskeleton rearrangement [169]. Gastric cancer-derived exosomes also have effect to M2 macrophage [170].

On the other hand, it has been also reported that gastric cancer-derived exosomes activate the NF-kB pathway in recipient macrophages, leading to up-regulation of pro-inflammatory factors [171] such as IL-6 and TNF- $\alpha$ which promote gastric cancer progression [172]. A similar result was also reported that breast cancer cell line-derived exosome stimulates the NF-kB pathway in macrophages, which leads to the secretion of proinflammatory factors such as IL- 6 , TNF- $\alpha$, GCSF, and 
CCL2 [173]. Breast cancer exosomal protein HSP72 and RNAs are involved in stimulating the NK-kB pathway. It was also demonstrated that breast cancer-derived exosomes promote macrophage polarization and induce lymph node metastasis [174]. It has been also shown that breast cancer-derived exosomes are enriched with gp130, which induces gp130/STATS signaling in macrophage and leads to the secretion of IL- 6 for macrophage polarization [175]. From this point of view, tumorderived exosomes are assumed to play both antiinflammatory and pro-inflammatory roles by stimulating M2 and M1 macrophages, respectively.

TAM-derived exosomes also participate in tumorigenesis. For example, TAM-derived exosomes enhance tumor invasion by delivering wnt5a in macrophages to breast cancer cells. Delivered wnt5a enhances tumor invasion by leading to the activation of $\beta$-cateninindependent Wnt signaling [176].

\section{Conclusion}

Since exosomes are known as cellular communicators, there are many approaches for isolation and exosomal content analysis. Sadly, the big hurdles of exosome research still remain. The establishment of isolation and digestion standards remain essential. In this review, we briefly summarized the current methods of exosome isolation and its protein digestion. For cell supernatant exosome analysis, exosomes are isolated by combined methods and proteins are digested mostly by In-Gel digestion and FASP. Body fluid exosomes are isolated by the same methods, but proteins are digested by FASP for mass spectrometry.

Cancer-derived exosomes contain various proteins. Exosomal proteins from cancer cells affect the tumor microenvironment in their favor through suppressive modulation of immune cells including NK cells, T cells, and Macrophages and immune surveillance. Cancer stem cell progression and chemotherapy resistance are acquired by modulating cancer associated fibroblasts. Together, cancer-derived exosomes and tumor microenvironment cell-derived exosomes alter the cancers to be more aggressive and be able to metastasize. In the process, these tumor-derived exosomes are enriched and can be detected in biological fluids. Recent discoveries in exosome fields will also alter cancer management. Indeed, non-invasive diagnosis and prognosis could become possible via plasma exosomes. Thus, it is suggested that strategies based on the blocking of exosomal immune suppression could be developed for the treatment of cancer patients. Since exosome fields are expanding, further efforts to reveal fundamental mechanisms of exosome cargo selection and biogenesis are necessary to fully understand the roles of proteins in exosomes.

\section{Acknowledgements}

We thank Johannes Josephus Schabort (Department of Veterinary Biochemistry, Seoul National University, Seoul, Korea) his English grammatical corrections of this manuscript.

\section{Authors' contributions}

HJC contributed in the conceptions and approval of this manuscript. HK, DK and JC drafted and wrote the manuscript. All authors read and approved the final manuscript.

\section{Funding}

This research was supported by the Bio \& Medical Technology Development Program of the National Research Foundation (NRF) funded by the Ministry of Science and ICT (\#2016M3A9B6026771 \& \#2014M3A9D5A01073598).

Availability of data and materials

Not applicable.

Ethics approval and consent to participate

Not applicable.

Consent for publication

Not applicable.

\section{Competing interests}

The authors declare that they have no competing interests.

Received: 12 June 2019 Accepted: 15 October 2019

Published online: 29 October 2019

\section{References}

1. Maia J, Caja S, Strano Moraes MC, Couto N, Costa-Silva B. Exosome-Based Cell-Cell Communication in the Tumor Microenvironment. Front Cell Dev Biol. 2018;6:18.

2. Seo N, Akiyoshi K, Shiku H. Exosome-mediated regulation of tumor immunology. Cancer Sci. 2018;109:2998-3004.

3. Tao L, Shi J, Yang X, Yang L, Hua F. The Exosome: a New Player in Diabetic Cardiomyopathy. J Cardiovasc Transl Res. 2019;12:62-7.

4. Das CK, Jena BC, Banerjee I, Das S, Parekh A, Bhutia SK, Mandal M. Exosome as a Novel Shuttle for Delivery of Therapeutics across Biological Barriers. Mol Pharm. 2019;16:24-40.

5. Wortzel I, Dror S, Kenific CM, Lyden D. Exosome-Mediated Metastasis: Communication from a Distance. Dev Cell. 2019;49:347-60.

6. Chen Y, Li G, Liu ML. Microvesicles as Emerging Biomarkers and Therapeutic Targets in Cardiometabolic Diseases. Genomics Proteomics Bioinformatics. 2018:16:50-62.

7. Kourembanas S. Exosomes: vehicles of intercellular signaling, biomarkers, and vectors of cell therapy. Annu Rev Physiol. 2015:77:13-27.

8. Sunkara V, Woo HK, Cho YK. Emerging techniques in the isolation and characterization of extracellular vesicles and their roles in cancer diagnostics and prognostics. Analyst. 2016;141:371-81

9. Melo SA, Sugimoto H, O'Connell JT, Kato N, Villanueva A, Vidal A, Qiu L, Vitkin E, Perelman LT, Melo CA, et al. Cancer exosomes perform cellindependent microRNA biogenesis and promote tumorigenesis. Cancer Cell. 2014:26:707-21.

10. Rana S, Malinowska K, Zoller M. Exosomal tumor microRNA modulates premetastatic organ cells. Neoplasia. 2013;15:281-95.

11. Henderson MC, Azorsa DO. The genomic and proteomic content of cancer cell-derived exosomes. Front Oncol. 2012:2:38

12. Properzi F, Logozzi M, Fais S. Exosomes: the future of biomarkers in medicine. Biomark Med. 2013:7:769-78.

13. Alegre E, Zubiri L, Perez-Gracia JL, Gonzalez-Cao M, Soria L, Martin-Algarra S, Gonzalez A. Circulating melanoma exosomes as diagnostic and prognosis biomarkers. Clin Chim Acta. 2016:454:28-32.

14. Roberson CD, Atay S, Gercel-Taylor C, Taylor DD. Tumor-derived exosomes as mediators of disease and potential diagnostic biomarkers. Cancer Biomark. 2010;8:281-91.

15. Taylor DD, Gercel-Taylor C. MicroRNA signatures of tumor-derived exosomes as diagnostic biomarkers of ovarian cancer. Gynecol Oncol. 2008;110:13-21.

16. Tavakolizadeh J, Roshanaei K, Salmaninejad A, Yari R, Nahand JS, Sarkarizi HK, Mousavi SM, Salarinia R, Rahmati M, Mousavi SF, et al. MicroRNAs and 
exosomes in depression: Potential diagnostic biomarkers. J Cell Biochem. 2018;119:3783-97.

17. Witwer KW, Buzas El, Bemis LT, Bora A, Lasser C, Lotvall J, Nolte-'t Hoen EN, Piper MG, Sivaraman S, Skog J, et al. Standardization of sample collection, isolation and analysis methods in extracellular vesicle research. J Extracell Vesicles. 2013:2(1):20360.

18. Yamashita T, Takahashi Y, Nishikawa M, Takakura Y. Effect of exosome isolation methods on physicochemical properties of exosomes and clearance of exosomes from the blood circulation. Eur J Pharm Biopharm. 2016;98:1-8.

19. Muller L, Hong CS, Stolz DB, Watkins SC, Whiteside TL. Isolation of biologically-active exosomes from human plasma. J Immunol Methods. 2014;411:55-65.

20. Choksawangkarn W, Edwards N, Wang Y, Gutierrez P, Fenselau C. Comparative study of workflows optimized for in-gel, in-solution, and onfilter proteolysis in the analysis of plasma membrane proteins. J Proteome Res. 2012;11:3030-4.

21. Kim YI, Cho JY. Gel-based proteomics in disease research: Is it still valuable? Biochim Biophys Acta Proteins Proteom. 1867;2019:9-16.

22. Ludwig KR, Schroll MM, Hummon AB. Comparison of In-Solution, FASP, and S-Trap Based Digestion Methods for Bottom-Up Proteomic Studies. J Proteome Res. 2018;17:2480-90.

23. Soekmadji C, Riches JD, Russell PJ, Ruelcke JE, McPherson S, Wang C, Hovens CM, Corcoran NM. Australian Prostate Cancer Collaboration B, Hill MM, Nelson CC: Modulation of paracrine signaling by CD9 positive small extracellular vesicles mediates cellular growth of androgen deprived prostate cancer. Oncotarget. 2017:8:52237-55.

24. Gangoda L, Liem M, Ang CS, Keerthikumar S, Adda CG, Parker BS, Mathivanan S. Proteomic Profiling of Exosomes Secreted by Breast Cancer Cells with Varying Metastatic Potential. Proteomics. 2017;17(23-24). https:/ doi.org/10.1002/pmic.201600370.

25. Bisaro B, Mandili G, Poli A, Piolatto A, Papa V, Novelli F, Cenacchi G, Forni M, Zanini C. Proteomic analysis of extracellular vesicles from medullospheres reveals a role for iron in the cancer progression of medulloblastoma. Mol Cell Ther. 2015;3:8.

26. Garnier D, Magnus N, Meehan B, Kislinger T, Rak J. Qualitative changes in the proteome of extracellular vesicles accompanying cancer cell transition to mesenchymal state. Exp Cell Res. 2013:319:2747-57.

27. Fan J, Wei Q, Koay EJ, Liu Y, Ning B, Bernard PW, Zhang N, Han H, Katz MH, Zhao Z, Hu Y. Chemoresistance Transmission via Exosome-Mediated EphA2 Transfer in Pancreatic Cancer. Theranostics. 2018;8:5986-94.

28. Ono K, Eguchi T, Sogawa C, Calderwood SK, Futagawa J, Kasai T, Seno M, Okamoto K, Sasaki A, Kozaki KI. HSP-enriched properties of extracellular vesicles involve survival of metastatic oral cancer cells. J Cell Biochem. 2018; 119:7350-62.

29. Greening DW, Ji H, Chen M, Robinson BW, Dick IM, Creaney J, Simpson RJ. Secreted primary human malignant mesothelioma exosome signature reflects oncogenic cargo. Sci Rep. 2016;6:32643.

30. Yi H, Zheng X, Song J, Shen R, Su Y, Lin D. Exosomes mediated pentose phosphate pathway in ovarian cancer metastasis: a proteomics analysis. Int J Clin Exp Pathol. 2015;8:15719-28.

31. Blomme A, Fahmy K, Peulen O, Costanza B, Fontaine M, Struman I, Baiwir D, de Pauw E, Thiry M, Bellahcene A, et al. Myoferlin is a novel exosomal protein and functional regulator of cancer-derived exosomes. Oncotarget. 2016;7:83669-83.

32. Hoshino A, Costa-Silva B, Shen TL, Rodrigues G, Hashimoto A, Tesic Mark M, Molina H, Kohsaka S, Di Giannatale A, Ceder S, et al. Tumour exosome integrins determine organotropic metastasis. Nature. 2015;527:329-35.

33. Mathivanan S, Lim JW, Tauro BJ, Ji H, Moritz RL, Simpson RJ. Proteomics analysis of A33 immunoaffinity-purified exosomes released from the human colon tumor cell line LIM1215 reveals a tissue-specific protein signature. Mol Cell Proteomics. 2010;9:197-208.

34. Leca J, Martinez S, Lac S, Nigri J, Secq V, Rubis M, Bressy C, Serge A, Lavaut MN, Dusetti N, et al. Cancer-associated fibroblast-derived annexin A6+ extracellular vesicles support pancreatic cancer aggressiveness. J Clin Invest. 2016;126:4140-56.

35. Lee CH, Im EJ, Moon PG, Baek MC. Discovery of a diagnostic biomarker for colon cancer through proteomic profiling of small extracellular vesicles. BMC Cancer. 2018;18:1058.

36. Campos A, Salomon C, Bustos R, Diaz J, Martinez S, Silva V, Reyes C, DiazValdivia N, Varas-Godoy M, Lobos-Gonzalez L, Quest AF. Caveolin-1- containing extracellular vesicles transport adhesion proteins and promote malignancy in breast cancer cell lines. Nanomedicine. 2018;13:2597-609.

37. Turay D, Khan S, Diaz Osterman CJ, Curtis MP, Khaira B, Neidigh JW, Mirshahidi S, Casiano CA, Wall NR. Proteomic Profiling of Serum-Derived Exosomes from Ethnically Diverse Prostate Cancer Patients. Cancer Invest. 2016;34:1-11.

38. Sun Y, Zheng W, Guo Z, Ju Q, Zhu L, Gao J, Zhou L, Liu F, Xu Y, Zhan Q, et al. A novel TP53 pathway influences the HGS-mediated exosome formation in colorectal cancer. Sci Rep. 2016;6:28083.

39. Zhang J, Lu S, Zhou Y, Meng K, Chen Z, Cui Y, Shi Y, Wang T, He QY. Motile hepatocellular carcinoma cells preferentially secret sugar metabolism regulatory proteins via exosomes. Proteomics. 2017;17(13-14):1700130

40. Chaiyawat $P$, Weeraphan $C$, Netsirisawan $P$, Chokchaichamnankit $D$, Srisomsap C, Svasti J, Champattanachai V. Elevated O-GlcNAcylation of Extracellular Vesicle Proteins Derived from Metastatic Colorectal Cancer Cells. Cancer Genomics Proteomics. 2016;13:387-98.

41. Choi DY, You S, Jung JH, Lee JC, Rho JK, Lee KY, Freeman MR, Kim KP, Kim J. Extracellular vesicles shed from gefitinib-resistant nonsmall cell lung cancer regulate the tumor microenvironment. Proteomics. 2014;14:1845-56.

42. Choi DS, Lee JM, Park GW, Lim HW, Bang JY, Kim YK, Kwon KH, Kwon HJ, Kim KP, Gho YS. Proteomic analysis of microvesicles derived from human colorectal cancer cells. J Proteome Res. 2007;6:4646-55.

43. Lee JE, Moon PG, Cho YE, Kim YB, Kim IS, Park H, Baek MC. Identification of EDIL3 on extracellular vesicles involved in breast cancer cell invasion. J Proteomics. 2016;131:17-28.

44. Griffiths SG, Cormier MT, Clayton A, Doucette AA. Differential Proteome Analysis of Extracellular Vesicles from Breast Cancer Cell Lines by Chaperone Affinity Enrichment. Proteomes. 2017;5(4):25.

45. Klein-Scory S, Tehrani MM, Eilert-Micus C, Adamczyk KA, Wojtalewicz N, Schnolzer M, Hahn SA, Schmiegel W, Schwarte-Waldhoff I. New insights in the composition of extracellular vesicles from pancreatic cancer cells: implications for biomarkers and functions. Proteome Sci. 2014;12:50.

46. Choi DS, Choi DY, Hong BS, Jang SC, Kim DK, Lee J, Kim YK, Kim KP, Gho YS. Quantitative proteomics of extracellular vesicles derived from human primary and metastatic colorectal cancer cells. J Extracell Vesicles. 2012;1. https://doi.org/10.3402/jev.v1i0.18704.

47. Ji H, Greening DW, Barnes TW, Lim JW, Tauro BJ, Rai A, Xu R, Adda C, Mathivanan S, Zhao W, et al. Proteome profiling of exosomes derived from human primary and metastatic colorectal cancer cells reveal differential expression of key metastatic factors and signal transduction components. Proteomics. 2013;13:1672-86.

48. Mariscal J, Fernandez-Puente P, Calamia V, Abalo A, Santacana M, MatiasGuiu X, Lopez-Lopez R, Gil-Moreno A, Alonso-Alconada L, Abal M. Proteomic Characterization of Epithelial-Like Extracellular Vesicles in Advanced Endometrial Cancer. J Proteome Res. 2019;18:1043-53.

49. Suwakulsiri W, Rai A, Xu R, Chen M, Greening DW, Simpson RJ. Proteomic profiling reveals key cancer progression modulators in shed microvesicles released from isogenic human primary and metastatic colorectal cancer cell lines. Biochim Biophys Acta Proteins Proteom. 2018:140171. https://doi.org/ 10.1016/j.bbapap.2018.11.008.

50. Jerez S, Araya H, Thaler R, Charlesworth MC, Lopez-Solis R, Kalergis AM, Cespedes PF, Dudakovic A, Stein GS, van Wijnen AJ, Galindo M. Proteomic Analysis of Exosomes and Exosome-Free Conditioned Media From Human Osteosarcoma Cell Lines Reveals Secretion of Proteins Related to Tumor Progression. J Cell Biochem. 2017;118:351-60.

51. Clark DJ, Fondrie WE, Yang A, Mao L. Triple SILAC quantitative proteomic analysis reveals differential abundance of cell signaling proteins between normal and lung cancer-derived exosomes. J Proteomics. 2016;133:161-9.

52. Jingushi K, Uemura M, Ohnishi N, Nakata W, Fujita K, Naito T, Fujii R, Saichi N, Nonomura N, Tsujikawa K, Ueda K. Extracellular vesicles isolated from human renal cell carcinoma tissues disrupt vascular endothelial cell morphology via azurocidin. Int J Cancer. 2018;142:607-17.

53. Abramowicz A, Marczak L, Wojakowska A, Zapotoczny S, Whiteside TL, Widlak $P$, Pietrowska M. Harmonization of exosome isolation from culture supernatants for optimized proteomics analysis. PLoS One. 2018;13:e0205496.

54. Hallal S, Mallawaaratchy DM, Wei H, Ebrahimkhani S, Stringer BW, Day BW, Boyd AW, Guillemin GJ, Buckland ME, Kaufman KL. Extracellular Vesicles Released by Glioblastoma Cells Stimulate Normal Astrocytes to Acquire a Tumor-Supportive Phenotype Via p53 and MYC Signaling Pathways. Mol Neurobiol. 2019;56:4566-81.

55. Abramowicz A, Wojakowska A, Marczak L, Lysek-Gladysinska M, Smolarz M, Story MD, Polanska J, Widlak P, Pietrowska M. lonizing radiation affects the 
composition of the proteome of extracellular vesicles released by head-andneck cancer cells in vitro. J Radiat Res. 2019;60(3):289-297.

56. Pan D, Chen J, Feng C, Wu W, Wang Y, Tong J, Zhou D. Preferential Localization of MUC1 Glycoprotein in Exosomes Secreted by Non-Small Cell Lung Carcinoma Cells. Int J Mol Sci. 2019;20(2):323.

57. Arbelaiz A, Azkargorta M, Krawczyk M, Santos-Laso A, Lapitz A, Perugorria MJ, Erice O, Gonzalez E, Jimenez-Aguero R, Lacasta A, et al. Serum extracellular vesicles contain protein biomarkers for primary sclerosing cholangitis and cholangiocarcinoma. Hepatology. 2017;66:1125-43.

58. Clark DJ, Fondrie WE, Liao Z, Hanson PI, Fulton A, Mao L, Yang AJ. Redefining the Breast Cancer Exosome Proteome by Tandem Mass Tag Quantitative Proteomics and Multivariate Cluster Analysis. Anal Chem. 2015; 87:10462-9.

59. Atay S, Wilkey DW, Milhem M, Merchant M, Godwin AK. Insights into the Proteome of Gastrointestinal Stromal Tumors-Derived Exosomes Reveals New Potential Diagnostic Biomarkers. Mol Cell Proteomics. 2018;17:495-515.

60. Chen IH, Xue L, Hsu CC, Paez JS, Pan L, Andaluz H, Wendt MK, Iliuk $A B$, Zhu JK, Tao WA. Phosphoproteins in extracellular vesicles as candidate markers for breast cancer. Proc Natl Acad Sci U S A. 2017; 114:3175-80.

61. Wisniewski JR, Zougman A, Nagaraj N, Mann M. Universal sample preparation method for proteome analysis. Nat Methods. 2009;6:359-62.

62. Siegel R, Naishadham D, Jemal A. Cancer statistics, 2012. CA Cancer J Clin. 2012;62:10-29

63. Siegel RL, Miller KD, Jemal A. Cancer statistics, 2019. CA Cancer J Clin. 2019;69:7-34.

64. Kruger S, Abd Elmageed ZY, Hawke DH, Worner PM, Jansen DA, AbdelMageed AB, Alt EU, Izadpanah R. Molecular characterization of exosome-like vesicles from breast cancer cells. BMC Cancer. 2014;14:44.

65. Yamaguchi $\mathrm{H}$, Condeelis J. Regulation of the actin cytoskeleton in cancer cell migration and invasion. Biochim Biophys Acta. 1773;2007:642-52.

66. Kanojia D, Morshed RA, Zhang L, Miska JM, Qiao J, Kim JW, Pytel P, Balyasnikova IV, Lesniak MS. Ahmed AU: betalll-Tubulin Regulates Breast Cancer Metastases to the Brain. Mol Cancer Ther. 2015;14:1152-61.

67. Tang H, Wang Y, Zhang B, Xiong S, Liu L, Chen W, Tan G, Li H. High brain acid soluble protein 1(BASP1) is a poor prognostic factor for cervical cancer and promotes tumor growth. Cancer Cell Int. 2017;17:97.

68. Hsiao KC, Shih NY, Fang HL, Huang TS, Kuo CC, Chu PY, Hung YM, Chou SW, Yang YY, Chang GC, Liu KJ. Surface alpha-enolase promotes extracellular matrix degradation and tumor metastasis and represents a new therapeutic target. PLoS One. 2013;8:e69354.

69. Tu SH, Chang CC, Chen CS, Tam KW, Wang YJ, Lee CH, Lin HW, Cheng TC, Huang CS, Chu JS, et al. Increased expression of enolase alpha in human breast cancer confers tamoxifen resistance in human breast cancer cells. Breast Cancer Res Treat. 2010;121:539-53.

70. Ding C, Fan X, Wu G. Peroxiredoxin 1 - an antioxidant enzyme in cancer. J Cell Mol Med. 2017;21:193-202.

71. Bajor M, Zych AO, Graczyk-Jarzynka A, Muchowicz A, Firczuk M, Trzeciak L, Gaj P, Domagala A, Siernicka M, Zagozdzon A, et al. Targeting peroxiredoxin 1 impairs growth of breast cancer cells and potently sensitises these cells to prooxidant agents. Br J Cancer. 2018;119:873-84.

72. Chen R, Kang R, Fan XG, Tang D. Release and activity of histone in diseases. Cell Death Dis. 2014;5:e1370.

73. Pemberton AD, Brown JK, Inglis NF. Proteomic identification of interactions between histones and plasma proteins: implications for cytoprotection. Proteomics. 2010;10:1484-93.

74. Chen F, Wagner PD. 14-3-3 proteins bind to histone and affect both histone phosphorylation and dephosphorylation. FEBS Lett. 1994;347:128-32.

75. Nagai A, Sato T, Akimoto N, Ito A, Sumida M. Isolation and identification of histone $\mathrm{H} 3$ protein enriched in microvesicles secreted from cultured sebocytes. Endocrinology. 2005;146:2593-601.

76. Moon PG, Lee JE, Cho YE, Lee SJ, Chae YS, Jung JH, Kim IS, Park HY, Baek MC. Fibronectin on circulating extracellular vesicles as a liquid biopsy to detect breast cancer. Oncotarget. 2016;7:40189-99.

77. Purushothaman A, Bandari SK, Liu J, Mobley JA, Brown EE, Sanderson RD. Fibronectin on the Surface of Myeloma Cell-derived Exosomes Mediates Exosome-Cell Interactions. J Biol Chem. 2016;291:1652-63.

78. Parente L, Solito E. Annexin 1: more than an anti-phospholipase protein. Inflamm Res. 2004;53:125-32

79. Moraes LA, Ampomah PB, Lim LHK. Annexin A1 in inflammation and breast cancer: a new axis in the tumor microenvironment. Cell Adh Migr. 2018; 12(5):417-423
80. Okano M, Kumamoto K, Saito M, Onozawa H, Saito K, Abe N, Ohtake T, Takenoshita S. Upregulated Annexin A1 promotes cellular invasion in triplenegative breast cancer. Oncol Rep. 2015;33:1064-70.

81. Zhou X, Zhi X, Zhou P, Chen S, Zhao F, Shao Z, Ou Z, Yin L. Effects of ecto5'-nucleotidase on human breast cancer cell growth in vitro and in vivo. Oncol Rep. 2007;17:1341-6.

82. Zhi X, Chen S, Zhou P, Shao Z, Wang L, Ou Z, Yin L. RNA interference of ecto-5'-nucleotidase (CD73) inhibits human breast cancer cell growth and invasion. Clin Exp Metastasis. 2007;24:439-48.

83. Zhou P, Zhi X, Zhou T, Chen S, Li X, Wang L, Yin L, Shao Z, Ou Z. Overexpression of Ecto-5'-nucleotidase (CD73) promotes T-47D human breast cancer cells invasion and adhesion to extracellular matrix. Cancer Biol Ther. 2007;6:426-31.

84. Wang L, Zhou X, Zhou T, Ma D, Chen S, Zhi X, Yin L, Shao Z, Ou Z, Zhou P. Ecto-5'-nucleotidase promotes invasion, migration and adhesion of human breast cancer cells. J Cancer Res Clin Oncol. 2008;134:365-72.

85. Jin D, Fan J, Wang L, Thompson LF, Liu A, Daniel BJ, Shin T, Curiel TJ, Zhang B. CD73 on tumor cells impairs antitumor T-cell responses: a novel mechanism of tumor-induced immune suppression. Cancer Res. 2010;70:2245-55.

86. Joosse SA, Hannemann J, Spotter J, Bauche A, Andreas A, Muller V, Pantel K. Changes in keratin expression during metastatic progression of breast cancer: impact on the detection of circulating tumor cells. Clin Cancer Res. 2012;18:993-1003.

87. Dozier JH, Hiser L, Davis JA, Thomas NS, Tucci MA, Benghuzzi HA, Frankfurter A, Correia JJ, Lobert S. Beta class II tubulin predominates in normal and tumor breast tissues. Breast Cancer Res. 2003;5:R157-69.

88. Palazzolo G, Albanese NN. G DIC, Gygax D, Vittorelli ML, Pucci-Minafra I: Proteomic analysis of exosome-like vesicles derived from breast cancer cells. Anticancer Res. 2012;32:847-60.

89. Moon PG, Lee JE, Cho YE, Lee SJ, Jung JH, Chae YS, Bae HI, Kim YB, Kim IS, Park HY, Baek MC. Identification of Developmental Endothelial Locus-1 on Circulating Extracellular Vesicles as a Novel Biomarker for Early Breast Cancer Detection. Clin Cancer Res. 2016;22:1757-66.

90. Klinke DJ 2nd, Kulkarni YM, Wu Y, Byrne-Hoffman C. Inferring alterations in cell-to-cell communication in HER2+ breast cancer using secretome profiling of three cell models. Biotechnol Bioeng. 2014;111:1853-63.

91. Cascone T, McKenzie JA, Mbofung RM, Punt S, Wang Z, Xu C, Williams L, Wang Z, Bristow CA, Carugo A, et al. Increased Tumor Glycolysis Characterizes Immune Resistance to Adoptive T Cell Therapy. Cell Metab. 2018;27:977-87 e974.

92. Ganapathy-Kanniappan S. Linking tumor glycolysis and immune evasion in cancer: Emerging concepts and therapeutic opportunities. Biochim Biophys Acta Rev Cancer. 1868;2017:212-20.

93. Gill KS, Fernandes P, O'Donovan TR, McKenna SL, Doddakula KK, Power DG, Soden DM, Forde PF. Glycolysis inhibition as a cancer treatment and its role in an anti-tumour immune response. Biochim Biophys Acta. 1866:2016:87-105

94. Leal AC, Mizurini DM, Gomes T, Rochael NC, Saraiva EM, Dias MS, Werneck CC, Sielski MS, Vicente CP, Monteiro RQ. Tumor-Derived Exosomes Induce the Formation of Neutrophil Extracellular Traps: Implications For The Establishment of Cancer-Associated Thrombosis. Sci Rep. 2017:7:6438.

95. Khan S, Bennit HF, Turay D, Perez M, Mirshahidi S, Yuan Y, Wall NR. Early diagnostic value of survivin and its alternative splice variants in breast cancer. BMC Cancer. 2014;14:176.

96. Hannafon BN, Gin AL, Xu YF, Bruns M, Calloway CL, Ding WQ. Metastasisassociated protein 1 (MTA1) is transferred by exosomes and contributes to the regulation of hypoxia and estrogen signaling in breast cancer cells. Cell Commun Signal. 2019;17:13.

97. Yang SJ, Wang DD, Li J, Xu HZ, Shen HY, Chen X, Zhou SY, Zhong SL, Zhao $\mathrm{JH}$, Tang JH. Predictive role of GSTP1-containing exosomes in chemotherapy-resistant breast cancer. Gene. 2017;623:5-14.

98. Martinez VG, O'Neill S, Salimu J, Breslin S, Clayton A, Crown J, O'Driscoll L. Resistance to HER2-targeted anti-cancer drugs is associated with immune evasion in cancer cells and their derived extracellular vesicles. Oncoimmunology. 2017;6:e1362530

99. Wang T, Ning K, Lu TX, Sun X, Jin L, Qi X, Jin J, Hua D. Increasing circulating exosomes-carrying TRPC5 predicts chemoresistance in metastatic breast cancer patients. Cancer Sci. 2017:108:448-54.

100. Ning K, Wang T, Sun X, Zhang P, Chen Y, Jin J, Hua D. UCH-L1-containing exosomes mediate chemotherapeutic resistance transfer in breast cancer. J Surg Oncol. 2017;115:932-40. 
101. Steigedal TS, Toraskar J, Redvers RP, Valla M, Magnussen SN, Bofin AM, Opdahl S, Lundgren S, Eckhardt BL, Lamar JM. Nephronectin is correlated with poor prognosis in breast cancer and promotes metastasis via its integrin-binding motifs. Neoplasia. 2018:20:387-400.

102. Vardaki I, Ceder S, Rutishauser D, Baltatzis G, Foukakis T, Panaretakis T. Periostin is identified as a putative metastatic marker in breast cancerderived exosomes. Oncotarget. 2016;7:74966.

103. Lakshmanan I, Ponnusamy MP, Macha MA, Haridas D, Majhi PD, Kaur S, Jain M, Batra SK, Ganti AK. Mucins in lung cancer: diagnostic, prognostic, and therapeutic implications. J Thorac Oncol. 2015;10:19-27.

104. Lakshmanan I, Rachagani S, Hauke R, Krishn SR, Paknikar S, Seshacharyulu P, Karmakar S, Nimmakayala RK, Kaushik G, Johansson SL, et al. MUC5AC interactions with integrin beta4 enhances the migration of lung cancer cells through FAK signaling. Oncogene. 2016;35:4112-21.

105. Cai F, Zhu Q, Miao Y, Shen S, Su X, Shi Y. Desmoglein-2 is overexpressed in non-small cell lung cancer tissues and its knockdown suppresses NSCLC growth by regulation of p27 and CDK2. J Cancer Res Clin Oncol. 2017;143:59-69.

106. Al-Nedawi K, Meehan B, Micallef J, Lhotak V, May L, Guha A, Rak J. Intercellular transfer of the oncogenic receptor EGFRvIII by microvesicles derived from tumour cells. Nat Cell Biol. 2008;10:619-24.

107. Chen W, Hoffmann AD, Liu H, Liu X. Organotropism: new insights into molecular mechanisms of breast cancer metastasis. NPJ Precis Oncol. 2018;2:4.

108. Li Z, Zeng C, Nong Q, Long F, Liu J, Mu Z, Chen B, Wu D, Wu H. Exosomal Leucine-Rich-Alpha2-Glycoprotein 1 Derived from Non-Small-Cell Lung Cancer Cells Promotes Angiogenesis via TGF-beta Signal Pathway. Mol Ther Oncolytics. 2019;14:313-22.

109. Li Y, Zhang Y, Qiu F, Qiu Z. Proteomic identification of exosomal LRG1: a potential urinary biomarker for detecting NSCLC. Electrophoresis. 2011;32:1976-83.

110. Elahi S, Niki T, Hirashima M, Horton H. Galectin-9 binding to Tim-3 renders activated human CD4+ T cells less susceptible to HIV-1 infection. Blood. 2012;119:4192-204.

111. Sandfeld-Paulsen B, Aggerholm-Pedersen N, Baek R, Jakobsen K, Meldgaard P, Folkersen B, Rasmussen T, Varming K, Jørgensen M, Sorensen B. Exosomal proteins as prognostic biomarkers in non-small cell lung cancer. Molecular oncology. 2016;10:1595-602.

112. Vykoukal J, Sun N, Aguilar-Bonavides C, Katayama H, Tanaka I, Fahrmann JF, Capello M, Fujimoto J, Aguilar M, Wistuba II. Plasma-derived extracellular vesicle proteins as a source of biomarkers for lung adenocarcinoma. Oncotarget. 2017;8:95466.

113. Jakobsen KR, Paulsen BS, Bæk R, Varming K, Sorensen BS, Jørgensen MM. Exosomal proteins as potential diagnostic markers in advanced non-small cell lung carcinoma. Journal of extracellular vesicles. 2015;4:26659.

114. Huang SH, Li Y, Zhang J, Rong J, Ye S. Epidermal growth factor receptorcontaining exosomes induce tumor-specific regulatory $T$ cells. Cancer Invest. 2013;31:330-5.

115. Jakobsen KR, Paulsen BS, Baek R, Varming K, Sorensen BS, Jorgensen MM. Exosomal proteins as potential diagnostic markers in advanced non-small cell lung carcinoma. J Extracell Vesicles. 2015;4:26659.

116. Choi DS, Park JO, Jang SC, Yoon YJ, Jung JW, Choi DY, Kim JW, Kang JS, Park J, Hwang D, et al. Proteomic analysis of microvesicles derived from human colorectal cancer ascites. Proteomics. 2011;11:2745-51.

117. Shiromizu T, Kume H, Ishida M, Adachi J, Kano M, Matsubara H, Tomonaga T. Quantitation of putative colorectal cancer biomarker candidates in serum extracellular vesicles by targeted proteomics. Sci Rep. 2017;7:12782.

118. Ohshima K, Hatakeyama K, Kanto K, Ide T, Watanabe Y, Moromizato S, Wakabayashi-Nakao K, Sakura N, Yamaguchi K, Mochizuki T. Comparative proteomic analysis identifies exosomal Eps8 protein as a potential metastatic biomarker for pancreatic cancer. Oncol Rep. 2019;41:1019-34.

119. Costa-Silva B, Aiello NM, Ocean AJ, Singh S, Zhang H, Thakur BK, Becker A,

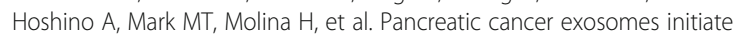
pre-metastatic niche formation in the liver. Nat Cell Biol. 2015;17:816-26.

120. Madhavan B, Yue S, Galli U, Rana S, Gross W, Muller M, Giese NA, Kalthoff H, Becker T, Buchler MW, Zoller M. Combined evaluation of a panel of protein and miRNA serum-exosome biomarkers for pancreatic cancer diagnosis increases sensitivity and specificity. Int J Cancer. 2015;136:2616-27.

121. Raimondo F, Morosi L, Corbetta S, Chinello C, Brambilla P, Della Mina P, Villa A, Albo G, Battaglia C, Bosari S, et al. Differential protein profiling of renal cell carcinoma urinary exosomes. Mol Biosyst. 2013;9:1220-33.
122. Seyfried TN, Huysentruyt LC. On the origin of cancer metastasis. Crit Rev Oncog. 2013;18:43-73.

123. Jie $X X$, Zhang $X Y, X u C J$. Epithelial-to-mesenchymal transition, circulating tumor cells and cancer metastasis: Mechanisms and clinical applications. Oncotarget. 2017;8:81558-71.

124. Quiroz-Munoz M, Izadmehr S, Arumugam D, Wong B, Kirschenbaum A, Levine AC. Mechanisms of Osteoblastic Bone Metastasis in Prostate Cancer: Role of Prostatic Acid Phosphatase. J Endocr Soc. 2019;3:655-64.

125. Medeiros B, Allan AL. Molecular Mechanisms of Breast Cancer Metastasis to the Lung: Clinical and Experimental Perspectives. Int J Mol Sci. 2019;20(9): 2272

126. Wang M, Zhao J, Zhang L, Wei F, Lian Y, Wu Y, Gong Z, Zhang S, Zhou J, Cao K, et al. Role of tumor microenvironment in tumorigenesis. J Cancer. 2017:8:761-73.

127. Varol C. Tumorigenic Interplay Between Macrophages and Collagenous Matrix in the Tumor Microenvironment. Methods Mol Biol. 1944;2019:203-20.

128. Segovia-Mendoza M, Morales-Montor J. Immune Tumor Microenvironment in Breast Cancer and the Participation of Estrogens and Its Receptors Into Cancer Physiopathology. Front Immunol. 2019;10:348.

129. Giese MA, Hind LE, Huttenlocher A. Neutrophil plasticity in the tumor microenvironment. Blood. 2019;133:2159-67.

130. Challagundla KB, Wise PM, Neviani P, Chava H, Murtadha M, Xu T, Kennedy R, Ivan C, Zhang X, Vannini I, et al. Exosome-mediated transfer of microRNAs within the tumor microenvironment and neuroblastoma resistance to chemotherapy. J Natl Cancer Inst. 2015;107(7). https://doi.org/10.1093/jnci/djv135.

131. Milane L, Singh A, Mattheolabakis G, Suresh M, Amiji MM. Exosome mediated communication within the tumor microenvironment. J Control Release. 2015;219:278-94.

132. Languino LR, Singh A, Prisco $M$, Inman GJ, Luginbuhl A, Curry JM, South AP. Exosome-mediated transfer from the tumor microenvironment increases TGFbeta signaling in squamous cell carcinoma. Am J Transl Res. 2016;8:2432-7.

133. Sun Z, Yang S, Zhou Q, Wang G, Song J, Li Z, Zhang Z, Xu J, Xia K, Chang Y, et al. Emerging role of exosome-derived long non-coding RNAs in tumor microenvironment. Mol Cancer. 2018;17:82.

134. Hu C, Chen M, Jiang R, Guo Y, Wu M, Zhang X. Exosome-related tumor microenvironment. J Cancer. 2018;9:3084-92.

135. Kalluri R. The biology and function of fibroblasts in cancer. Nat Rev Cancer. 2016;16:582-98.

136. Hwang RF, Moore T, Arumugam T, Ramachandran V, Amos KD, Rivera A, Ji B, Evans DB, Logsdon CD. Cancer-associated stromal fibroblasts promote pancreatic tumor progression. Cancer Res. 2008;68:918-26.

137. Xu Y, Lu Y, Song J, Dong B, Kong W, Xue W, Zhang J, Huang Y. Cancerassociated fibroblasts promote renal cell carcinoma progression. Tumour Biol. 2015;36:3483-8

138. Wei L, Ye H, Li G, Lu Y, Zhou Q, Zheng S, Lin Q, Liu Y, Li Z, Chen R. Cancerassociated fibroblasts promote progression and gemcitabine resistance via the SDF-1/SATB-1 pathway in pancreatic cancer. Cell Death Dis. 2018;9:1065.

139. Silva TA, Smuczek B, Valadao IC, Dzik LM, Iglesia RP, Cruz MC, Zelanis A, de Siqueira AS, Serrano SM, Goldberg GS, et al. AHNAK enables mammary carcinoma cells to produce extracellular vesicles that increase neighboring fibroblast cell motility. Oncotarget. 2016;7:49998-50016.

140. Takasugi M, Okada R, Takahashi A, Virya Chen D, Watanabe S, Hara E. Small extracellular vesicles secreted from senescent cells promote cancer cell proliferation through EphA2. Nat Commun. 2017;8:15729.

141. Richards KE, Zeleniak AE, Fishel ML, Wu J, Littlepage LE, Hill R. Cancerassociated fibroblast exosomes regulate survival and proliferation of pancreatic cancer cells. Oncogene. 2017;36:1770-8.

142. Ringuette Goulet C, Bernard G, Tremblay S, Chabaud S, Bolduc S, Pouliot F. Exosomes Induce Fibroblast Differentiation into Cancer-Associated Fibroblasts through TGFbeta Signaling. Mol Cancer Res. 2018;16:1196-204.

143. Li W, Zhang X, Wang J, Li M, Cao C, Tan J, Ma D, Gao Q. TGFbeta1 in fibroblasts-derived exosomes promotes epithelial-mesenchymal transition of ovarian cancer cells. Oncotarget. 2017:8:96035-47.

144. Wang L, Cao L, Wang H, Liu B, Zhang Q, Meng Z, Wu X, Zhou Q, Xu K. Cancer-associated fibroblasts enhance metastatic potential of lung cancer cells through IL-6/STAT3 signaling pathway. Oncotarget. 2017:8:76116-28.

145. Hu Y, Yan C, Mu L, Huang K, Li X, Tao D, Wu Y, Qin J. Fibroblast-Derived Exosomes Contribute to Chemoresistance through Priming Cancer Stem Cells in Colorectal Cancer. PLoS One. 2015;10:e0125625. 
146. Wen C, Seeger RC, Fabbri M, Wang L, Wayne AS, Jong AY. Biological roles and potential applications of immune cell-derived extracellular vesicles. J Extracell Vesicles. 2017;6:1400370.

147. Jong AY, Wu CH, Li J, Sun J, Fabbri M, Wayne AS, Seeger RC. Large-scale isolation and cytotoxicity of extracellular vesicles derived from activated human natural killer cells. J Extracell Vesicles. 2017;6:1294368.

148. Lundholm M, Schroder M, Nagaeva O, Baranov V, Widmark A, MinchevaNilsson L, Wikstrom P. Prostate tumor-derived exosomes down-regulate NKG2D expression on natural killer cells and CD8+ T cells: mechanism of immune evasion. PLoS One. 2014;9:e108925.

149. Berchem G, Noman MZ, Bosseler M, Paggetti J, Baconnais S, Le Cam E, Nanbakhsh A, Moussay E, Mami-Chouaib F, Janji B, Chouaib S. Hypoxic tumor-derived microvesicles negatively regulate NK cell function by a mechanism involving TGF-beta and miR23a transfer. Oncoimmunology. 2016:5:e1062968.

150. Xia Y, Zhang Q, Zhen Q, Zhao Y, Liu N, Li T, Hao Y, Zhang Y, Luo C, Wu X. Negative regulation of tumor-infiltrating NK cell in clear cell renal cell carcinoma patients through the exosomal pathway. Oncotarget 2017:8:37783-95

151. Zhu MC, Xiong P, Li GL, Zhu M. Could lung cancer exosomes induce apoptosis of natural killer cells through the p75NTR-proNGF-sortilin axis? Med Hypotheses. 2017;108:151-3.

152. Wang Y, Qin X, Zhu X, Chen W, Zhang J, Chen W. Oral cancer-derived exosomal NAP1 enhances cytotoxicity of natural killer cells via the IRF-3 pathway. Oral Oncol. 2018;76:34-41.

153. Abusamra AJ, Zhong Z, Zheng X, Li M, Ichim TE, Chin JL, Min WP. Tumor exosomes expressing Fas ligand mediate CD8+ T-cell apoptosis. Blood Cells Mol Dis. 2005:35:169-73.

154. Huber V, Fais S, lero M, Lugini L, Canese P, Squarcina P, Zaccheddu A, Colone M, Arancia G, Gentile M, et al. Human colorectal cancer cells induce T-cell death through release of proapoptotic microvesicles: role in immune escape. Gastroenterology. 2005;128:1796-804

155. Bergmann C, Strauss L, Wieckowski E, Czystowska M, Albers A, Wang Y, Zeidler R, Lang S, Whiteside TL. Tumor-derived microvesicles in sera of patients with head and neck cancer and their role in tumor progression. Head Neck. 2009:31:371-80.

156. Poggio M, Hu T, Pai CC, Chu B, Belair CD, Chang A, Montabana E, Lang UE, Fu Q, Fong L, Blelloch R. Suppression of Exosomal PD-L1 Induces Systemic Anti-tumor Immunity and Memory. Cell. 2019;177:414-27 e413.

157. Rong L, Li R, Li S, Luo R. Immunosuppression of breast cancer cells mediated by transforming growth factor-beta in exosomes from cancer cells. Oncol Lett. 2016;11:500-4.

158. Yamada N, Kuranaga Y, Kumazaki M, Shinohara H, Taniguchi K, Akao Y. Colorectal cancer cell-derived extracellular vesicles induce phenotypic alteration of T cells into tumor-growth supporting cells with transforming growth factor-beta1-mediated suppression. Oncotarget. 2016;7:27033-43.

159. Liu VC, Wong LY, Jang T, Shah AH, Park I, Yang X, Zhang Q, Lonning S, Teicher BA, Lee C. Tumor evasion of the immune system by converting CD4+CD25- T cells into CD4+CD25+ T regulatory cells: role of tumorderived TGF-beta. J Immunol. 2007;178:2883-92.

160. Chen W, Jiang J, Xia W, Huang J. Tumor-Related Exosomes Contribute to Tumor-Promoting Microenvironment: An Immunological Perspective. J Immunol Res. 2017;2017:1073947.

161. Linden J, Cekic C. Regulation of lymphocyte function by adenosine. Arterioscler Thromb Vasc Biol. 2012:32:2097-103.

162. Deaglio S, Dwyer KM, Gao W, Friedman D, Usheva A, Erat A, Chen JF, Enjyoji K, Linden J, Oukka M, et al. Adenosine generation catalyzed by CD39 and CD73 expressed on regulatory T cells mediates immune suppression. J Exp Med. 2007;204:1257-65.

163. Cedeno-Laurent F, Dimitroff CJ. Galectin-1 research in T cell immunity: past, present and future. Clin Immunol. 2012;142:107-16.

164. Maybruck BT, Pfannenstiel LW, Diaz-Montero M, Gastman BR. Tumor-derived exosomes induce CD8(+) T cell suppressors. J Immunother Cancer. 2017:5:65.

165. Martinez FO, Gordon S. The M1 and M2 paradigm of macrophage activation: time for reassessment. F1000Prime Rep. 2014;6:13.

166. Yang L, Zhang Y. Tumor-associated macrophages: from basic research to clinical application. J Hematol Oncol. 2017;10:58.

167. Baay M, Brouwer A, Pauwels P, Peeters M, Lardon F. Tumor cells and tumorassociated macrophages: secreted proteins as potential targets for therapy. Clin Dev Immunol. 2011;2011:565187.
168. Aras S, Zaidi MR. TAMeless traitors: macrophages in cancer progression and metastasis. Br J Cancer. 2017:117:1583-91.

169. Chen Z, Yang L, Cui Y, Zhou Y, Yin X, Guo J, Zhang G, Wang T, He QY. Cytoskeleton-centric protein transportation by exosomes transforms tumorfavorable macrophages. Oncotarget. 2016;7:67387-402.

170. Zheng P, Luo Q, Wang W, Li J, Wang T, Wang P, Chen L, Zhang P, Chen H, Liu $Y$, et al. Tumor-associated macrophages-derived exosomes promote the migration of gastric cancer cells by transfer of functional Apolipoprotein $\mathrm{E}$. Cell Death Dis. 2018;9:434.

171. Zhang $X$, Shi H, Yuan X, Jiang P, Qian H, Xu W. Tumor-derived exosomes induce N2 polarization of neutrophils to promote gastric cancer cell migration. Mol Cancer. 2018;17:146.

172. Wu L, Zhang X, Zhang B, Shi H, Yuan X, Sun Y, Pan Z, Qian H, Xu W. Exosomes derived from gastric cancer cells activate NF-kappaB pathway in macrophages to promote cancer progression. Tumour Biol. 2016;37:12169-80

173. Chow A, Zhou W, Liu L, Fong MY, Champer J, Van Haute D, Chin AR, Ren X, Gugiu BG, Meng Z, et al. Macrophage immunomodulation by breast cancerderived exosomes requires Toll-like receptor 2-mediated activation of NFkappaB. Sci Rep. 2014;4:5750.

174. Piao YJ, Kim HS, Hwang EH, Woo J, Zhang M, Moon WK. Breast cancer cellderived exosomes and macrophage polarization are associated with lymph node metastasis. Oncotarget. 2018;9:7398-410.

175. Ham S, Lima LG, Chai EPZ, Muller A, Lobb RJ, Krumeich S, Wen SW Wiegmans AP, Moller A. Breast Cancer-Derived Exosomes Alter Macrophage Polarization via gp130/STAT3 Signaling. Front Immunol. 2018:9:871.

176. Menck K, Klemm F, Gross JC, Pukrop T, Wenzel D, Binder C. Induction and transport of Wnt 5a during macrophage-induced malignant invasion is mediated by two types of extracellular vesicles. Oncotarget. 2013;4:2057-66.

\section{Publisher's Note}

Springer Nature remains neutral with regard to jurisdictional claims in published maps and institutional affiliations.
Ready to submit your research? Choose BMC and benefit from:

- fast, convenient online submission

- thorough peer review by experienced researchers in your field

- rapid publication on acceptance

- support for research data, including large and complex data types

- gold Open Access which fosters wider collaboration and increased citations

- maximum visibility for your research: over $100 \mathrm{M}$ website views per year

At $\mathrm{BMC}$, research is always in progress.

Learn more biomedcentral.com/submissions 